\title{
Novel and efficient texturing approach for large-scale industrial production line of large-area monocrystalline silicon solar cell
}

\author{
U. Gangopadhyay $\cdot$ S. Jana $\cdot$ S. Das $\cdot$ \\ P. Ghosh
}

Received: 7 July 2012/ Accepted: 14 June 2013/Published online: 28 June 2013

(C) The Author(s) 2013. This article is published with open access at Springerlink.com

\begin{abstract}
Texturing monocrystalline silicon (c-Si) for solar cell fabrication is still a key issue due to consumption of a large amount of costly isopropyl alcohol (IPA) in conventional $\mathrm{NaOH} / \mathrm{KOH}$ solution. Controlling IPA amount in $\mathrm{NaOH} / \mathrm{KOH}$-texturing bath for longer life of the solution in industrial batch production is a difficult task. This article reports the use of a chemical bath with a composition of $\mathrm{NaOH}-\mathrm{NaOCl}$ (sodium hydroxide-sodium hypochlorite) for texturing monocrystalline silicon surface for solar cell fabrication. We report such a novel concept of texturing of the c-Si surface without using IPA and discarding the saw damage removal step. The optimized etching condition with $\mathrm{NaOH}-\mathrm{NaOCl}$-containing solution does not have any negative effect on monocrystalline silicon solar cell efficiency. Easy control of the process due to the self-controlled reaction is one of the major advantages and there is no need of sophisticated temperature-controlling system during texturing in the industrial batch process. Moreover, FTIR analysis shows the formation of $\mathrm{Si}-\mathrm{Cl}$ bond during texturing, which improves the quality of diffused junction due to the gettering effect of $\mathrm{Cl}$. Solar cell of conversion efficiency $14.5-15.8 \%$ on CZ-Si substrate of area $125 \mathrm{~mm} \times 125 \mathrm{~mm}$ was successfully fabricated using a novel texturing approach in industrial production line with yield $>85 \%$.
\end{abstract}

Keywords Texturization $\cdot \mathrm{NaOH}-\mathrm{NaOCl}$ solution . Monocrystalline silicon · Inverted pyramids

U. Gangopadhyay $(\bowtie) \cdot$ S. Jana $\cdot$ S. Das $\cdot$ P. Ghosh

Meghnad Saha Institute of Technology, Nazirabad,

Kolkata 700107, India

e-mail: utpal_ganguly@yahoo.com

\section{Introduction}

Texturing of monocrystalline silicon is necessary for fabrication of better-quality solar cells. Therefore, industrial production of large-area monocrystalline silicon for solar cell fabrication needs effective and economically viable technique for texturing of monocrystalline silicon (c-Si). Conventionally, anisotropic chemical etching of silicon is performed with a mixture of alkaline solution of sodium hydroxide $(\mathrm{NaOH})$ or potassium hydroxide $(\mathrm{KOH})$, and isopropyl alcohol (IPA) is widely used for texturing of monocrystalline silicon wafers [1-3]. In a typical texturing condition, the IPA concentration is higher than the $\mathrm{NaOH}$ (or $\mathrm{KOH}$ ) concentration. IPA increases the wettability of silicon surface, but increasing IPA concentration beyond a limit decreases the rate of silicon removal very strongly [1]. Therefore, excessive IPA addition to the texturing solution leads to the detrimental effect of no texturization even after long-time treatment. Moreover, IPA is a volatile compound and so it has to be added frequently to the texturization bath during the batch process to compensate for the evaporated amount, leading to a higher consumption of IPA. Controlling IPA amount in $\mathrm{NaOH} / \mathrm{KOH}$-texturing bath for longer life of the solution in the industrial batch production is a difficult task [4]. IPA is also expensive. All these together are the constraints of $\mathrm{NaOH} / \mathrm{KOH}$-texturing processes during monocrystalline silicon solar cell fabrication in large-scale industrial production line. However, due to the high cost of IPA and constraint on controlling its excess amount, there is always a search for an alternate chemical composition for texturing without using IPA. So, elimination of IPA during texturing of the commercial solar cell fabrication is the key issue of the overall texturing cost reduction approach, as well as maintenance of the continuous flow of texturing batch process in industrial

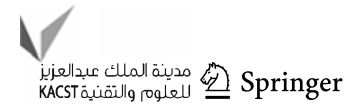


process line. To overcome these constraints, use of sodium carbonate $\left(\mathrm{Na}_{2} \mathrm{CO}_{3}\right)$ or potassium carbonate $\left(\mathrm{K}_{2} \mathrm{CO}_{3}\right)$ has been reported by some researchers $[5,6]$. This article reports the use of a chemical bath with a composition of $\mathrm{NaOH}-\mathrm{NaOCl}$ (sodium hydroxide-sodium hypochlorite) for texturing monocrystalline silicon surface without using IPA for solar cell fabrication. Moreover, this proposed novel concept for texturing of silicon surface also discards the saw damage removal step in the industrial production line. The optimized etching condition with $\mathrm{NaOH}-\mathrm{NaOCl}-$ containing solution does not have any negative effect on monocrystalline silicon solar cell efficiency. Self-controlling reaction is one of the major advantages of the $\mathrm{NaOH}-$ $\mathrm{NaOCl}$ texturization process, which leads to much less complicacies of using a temperature control system in the industrial batch process. The role of $\mathrm{NaOH}-\mathrm{NaOCl}$ solution for cleaning organic contaminations while texturing $\mathrm{c}-\mathrm{Si}$ and comparison of this process with conventional $\mathrm{NaOH}-\mathrm{IPA}$ approach have been reported in this paper.

\section{Experiment}

\section{Texturing}

In our experiment, we have used $C Z$ p-type, monocrystalline silicon (c-Si) with resistivity of about $0.5-2.0 \Omega \mathrm{cm}$ for texturing. In our texturization experiment, we varied the three different concentrations of $\mathrm{NaOH}$ solution (i.e., 10, 20 and $40 \%$ ) for a fixed $12 \% \mathrm{NaOCl}$ solution each time. The ratio of the amounts of $\mathrm{NaOH}$ to $\mathrm{NaOCl}$ also varied along with the time of etching. All the etched wafers were studied under optical microscope and etching thickness was studied with a standard gravimetric method. Scanning electron microscopy (SEM) and FTIR were studied for selected monocrystalline wafers. Evaluation of surface reflectance after texturing was also completed. We used all these measurement tools in the case of conventional $\mathrm{NaOH}-\mathrm{IPA}$ texturing and compared the results of the two different approaches.

\section{Solar cell fabrication}

During the solar cell fabrication experiment, textured $C Z$ p-type monocrystalline silicon (c-Si) wafers were diffused by pentavalent impurity (phosphorus) in an open-tube furnace using conventional $\mathrm{POCl}_{3}$ diffusion source at $850{ }^{\circ} \mathrm{C}$ for $7 \mathrm{~min}$ pre-deposition followed by $16 \mathrm{~min}$ drivein. PSG removal was done by short time dipping in BHF solution followed by DI-water rinsing and drying. The sheet resistance of $\mathrm{n}^{+}$emitter layer was $55-60 \Omega / \mathrm{sq}$. All textured $\mathrm{c}-\mathrm{Si}$ wafers were oxidized at $850{ }^{\circ} \mathrm{C}$ for $20 \mathrm{~min}$. After edge isolation and oxide layer removal, about $70 \mathrm{~nm}$ layer of SiNx (refractive index $\sim 2.0$ ) was deposited on the front side by means of PECVD at $450{ }^{\circ} \mathrm{C}$ for ARC. The front and back metallization of the diffused silicon wafers was carried out using standard Ag paste (product no. 3349, Ferro Electronic Materials) and Al paste (product no. Fx53038, Ferro Electronic Materials) for screen-printed metallization technique followed by baking and co-firing at the temperature of $750{ }^{\circ} \mathrm{C}$ in a conveyor belt furnace (SeirraTherm, USA).

The illuminated current-voltage (LIV) characteristics, dark current-voltage (DIV) characteristics of $\mathrm{NaOCl}-$ $\mathrm{NaOH}$-textured and conventional $\mathrm{NaOH}-\mathrm{IPA}$-textured c-Si solar cells were determined.

\section{Results and discussion}

For etching performance comparison with two different approaches, (a) proposed $\mathrm{NaOH}-\mathrm{NaOCl}$ solution and (b) conventional $\mathrm{NaOH}-\mathrm{IPA}$ solution, we used contaminated $\mathrm{c}-\mathrm{Si}$ wafers. Prior to the texturization experiment, FTIR analysis of the c-Si samples was done. From the FTIR analysis of the samples, it was observed that at the start all silicon wafers had significant contamination [7, 8] all over the surface as shown in Fig. 1. Three different values of concentration of $\mathrm{NaOH}$ such as 10, 20 and $40 \%$ were taken and the ratio of $\mathrm{NaOH}: \mathrm{NaOCl}$ was considered as 1:2 for the first four experiments. The etching time durations for those experiments were set between 15 and $20 \mathrm{~min}$. In the next set of experiment, mainly the ratio of $\mathrm{NaOH}: \mathrm{NaOCl}$ was varied in the textured solution and only three different time settings were considered. The details of the experimental conditions along with average reflectivity of the different etched monocrystalline silicon(c-Si)

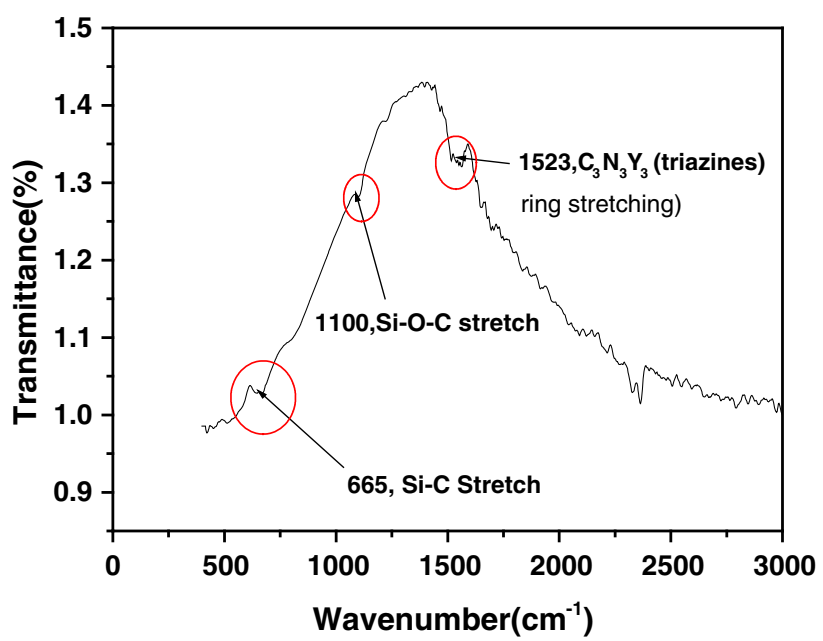

Fig. 1 FTIR analysis of the starting c-Si wafer before the texturization experiment 
Table 1 Different conditions of $\mathrm{NaOH}-\mathrm{NaOCl}$ texturing

\begin{tabular}{llllll}
\hline Sample ID & $\begin{array}{l}\text { Conc. of } \\
\mathrm{NaOH}(\%)\end{array}$ & $\begin{array}{l}\mathrm{Conc} \text { of } \\
\mathrm{NaOCl}(\%)\end{array}$ & $\mathrm{NaOH}: \mathrm{NaOCl}$ & $\begin{array}{l}\text { Time of } \\
\text { etching (min) }\end{array}$ & $\begin{array}{l}\text { Average } \\
\text { reflectivity (\%) }\end{array}$ \\
\hline S1 & 10 & 12 & $1: 2$ & 20 & 19.19 \\
S2 & 20 & 12 & $1: 2$ & 20 & 18.31 \\
S3 & 40 & 12 & $1: 2$ & 15 & 18.37 \\
S4 & 40 & 12 & $1: 2$ & 20 & 19.56 \\
S5 & 40 & 12 & $1: 3$ & 30 & 19.28 \\
S6 & 40 & 12 & $1: 4$ & 10 & 17.49 \\
S7 & 40 & 12 & $1: 4$ & 24 & 21.03 \\
S8 & 40 & 12 & $1: 5$ & 10 & 17.12 \\
S9 & 40 & 12 & $1: 5$ & 24 & 20.85 \\
S10 & 40 & 12 & $1: 6$ & 10 & 15.47 \\
\hline
\end{tabular}

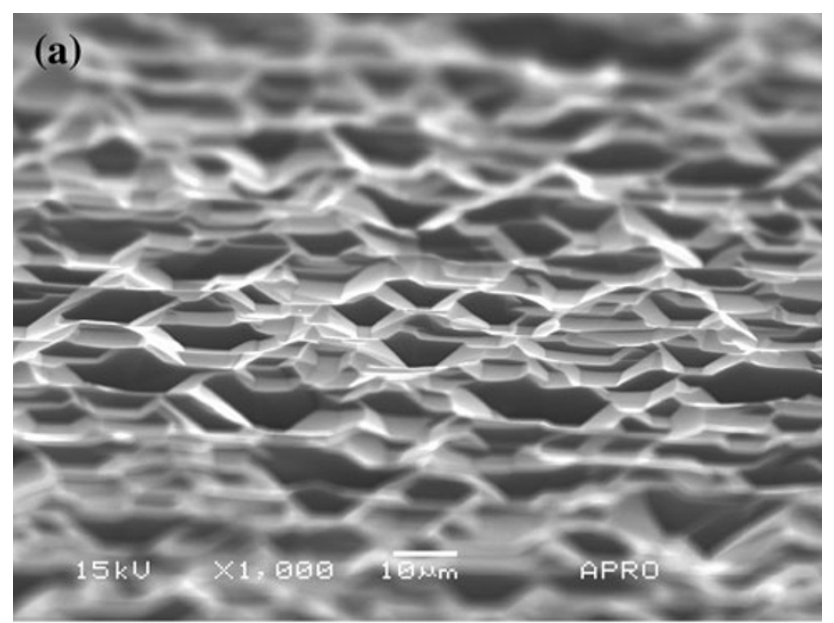

(b)

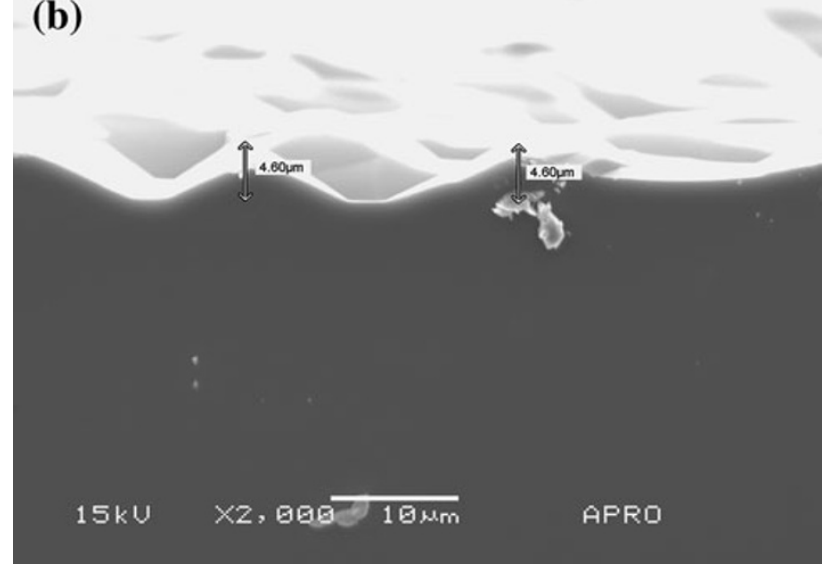

Fig. 2 SEM picture of $\mathrm{NaOH}-\mathrm{NaOCl}$-textured c-Si wafer: a surface, b cross-sectional edge view where $\mathrm{NaOH}(40 \%)$ : $\mathrm{NaOCl}=1: 2$, textured time $20 \mathrm{~min}$

surfaces are listed in Table 1. It was observed that the average reflectivity of the textured sample $\mathrm{S} 2$ was lowest compared to samples S1 and S3. This might be due to the different etching mechanism of $\mathrm{NaOH}-\mathrm{NaOCl}$ solution for different combination ratios. $\mathrm{As} \mathrm{NaOCl}$ is a strong oxidizing agent [9], it oxidizes the silicon layer first on

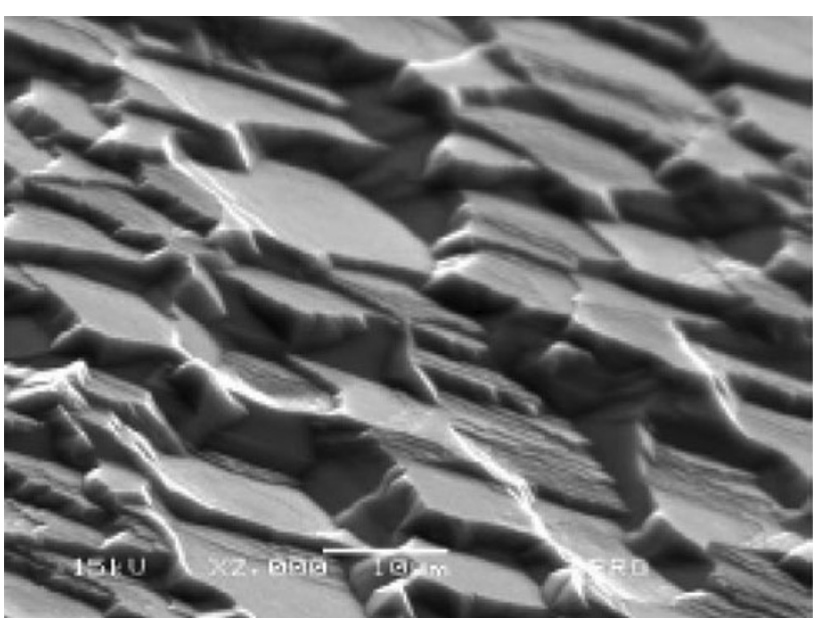

Fig. 3 Surface morphology of a typical $\mathrm{NaOH}-\mathrm{NaOCl}$-textured c-Si with higher $\mathrm{NaOH}$ and $\mathrm{NaOCl}$ ratio (for typical 1:4)

dipping in $\mathrm{NaOH}-\mathrm{NaOCl}$ solution. This was followed by etching due to the presence of $\mathrm{NaOH}$ in the solution. Moreover, as the silicon layer was chemically oxidized, the probability of growth of non-uniform oxide on the silicon layer was significantly large. Anisotropy of $\mathrm{NaOH}$ solution is highest at its $20 \%$ concentration [10]. The chance of inverted pyramidal structure formation through the automatically unintentionally formed oxide mask on the c-Si surface is more than that in the other two cases, i.e., 10 and $40 \%$ in $\mathrm{NaOH}: \mathrm{NaOCl}=1: 2$ ratio (sample $\mathrm{S} 1$ and $\mathrm{S} 2$ ). So, sample S2 was more textured than S1 and S3. This was probably due to the lowest average reflectance of sample S2 out of the three samples (S1, S2 and S3). The calculated standard deviation for reflectivity of the c-Si samples under the experiment is 1.7 using standard deviation formulas. Figure 2 shows the SEM micrograph of a typical $\mathrm{NaOH}-$ $\mathrm{NaOCl}$-textured surface with etching condition as mentioned in Table 1 for sample 2. Inverted pyramidal structures were formed at some places on the surface of c-Si as shown in Fig. 2a. The etch depth was around $4 \mu \mathrm{m}$ as

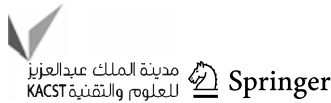



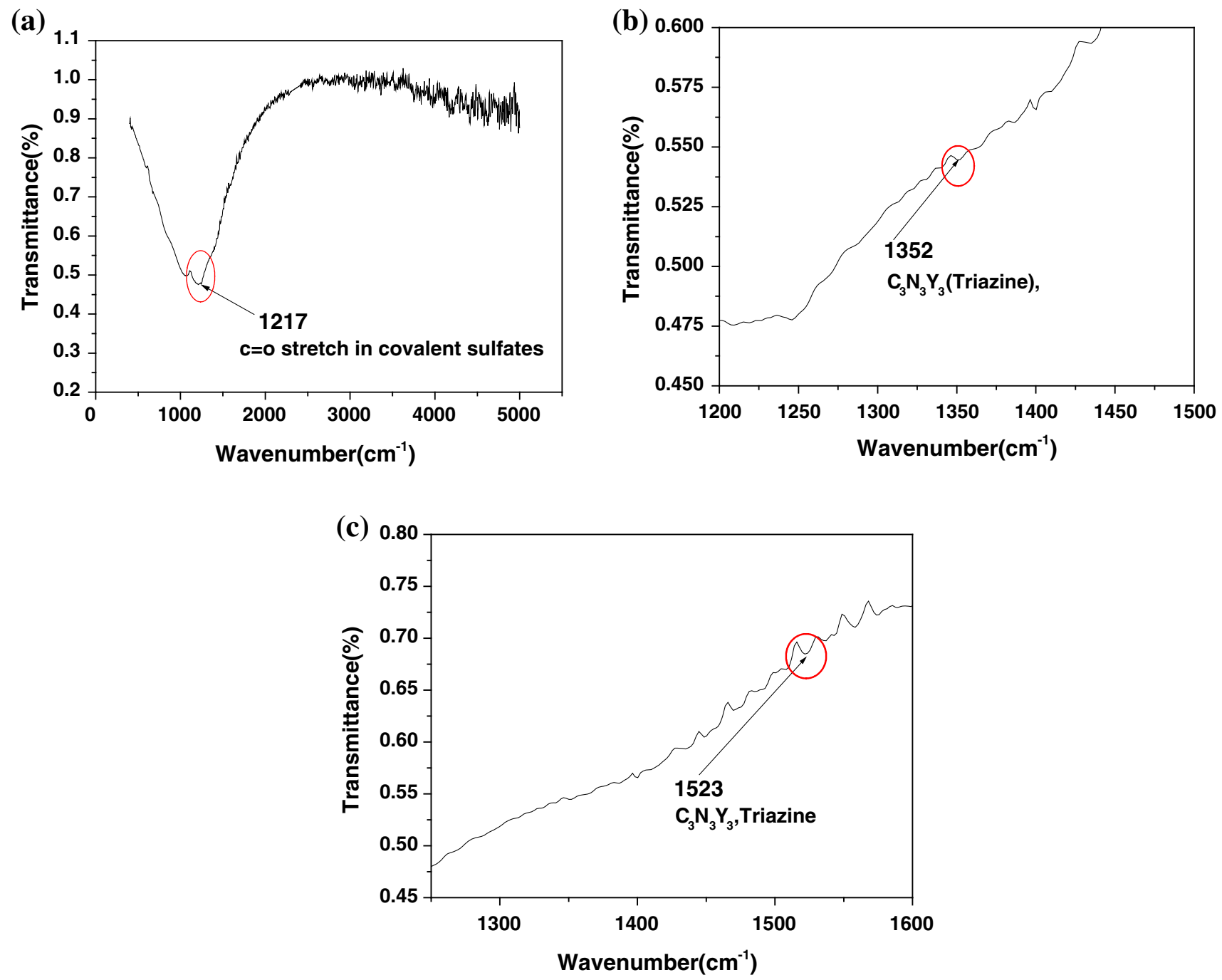

Fig. 4 FTIR analysis of $\mathrm{NaOH}-\mathrm{NaOCl}$ c-Si surface after short time texturing (10 min) of s samples S6, S8 and S10, respectively

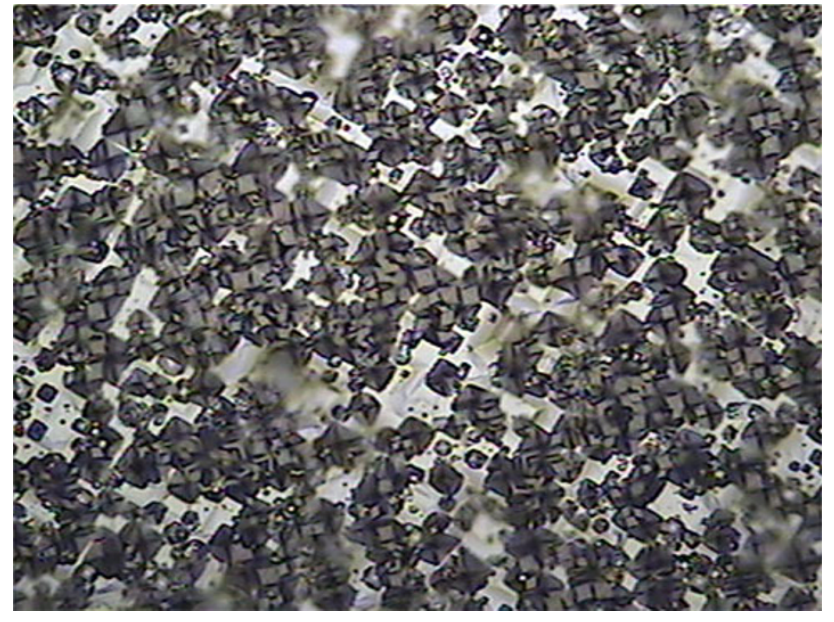

Fig. 5 Optical micrograph of a conventional NaOH-IPA-textured c-Si surface

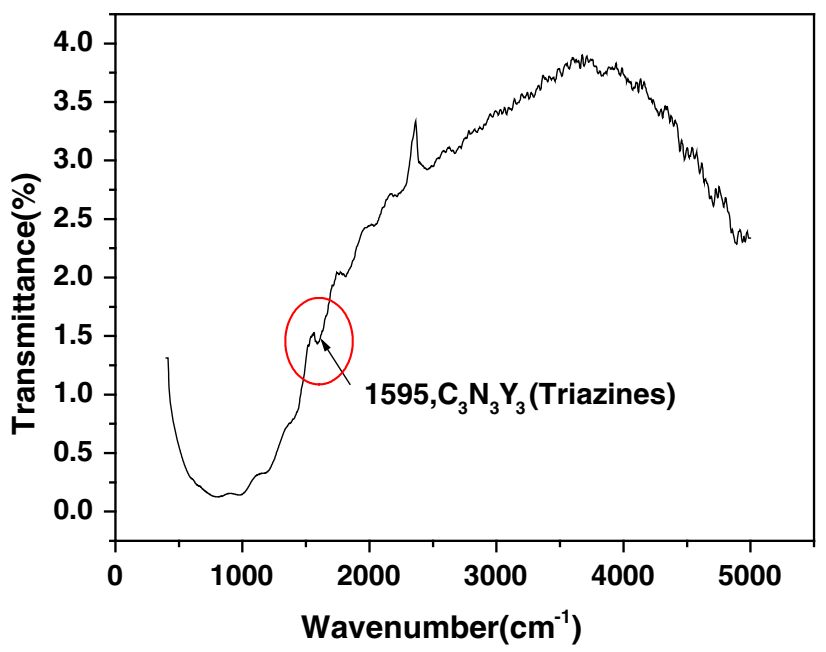

Fig. 6 FTIR analysis of NaOH-IPA-textured c-Si surface 


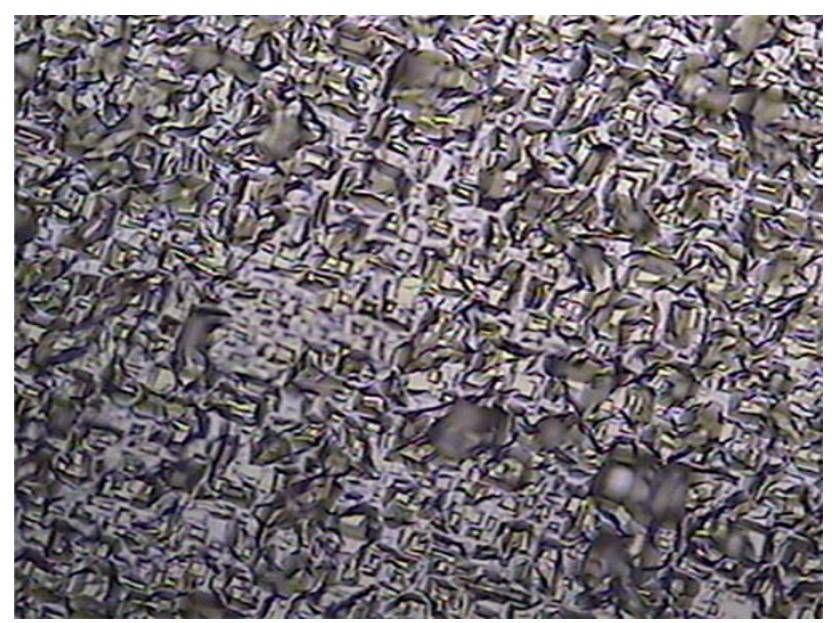

Fig. 7 Optical micrograph of a typical $\mathrm{NaOH}-\mathrm{NaOCl}$-textured c-Si surface (condition of texturization: concentration of NaOH: $20 \%$, concentration of $\mathrm{NaOCl}: 12 \%, \mathrm{NaOH}: \mathrm{NaOCl}=1: 2$ and time $=$ $20 \mathrm{~min}$.)

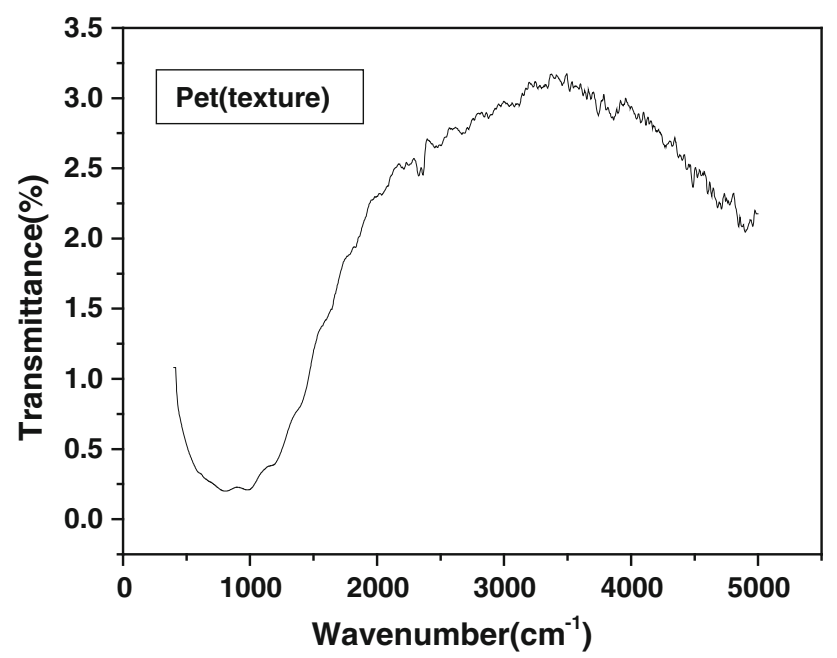

Fig. 8 FTIR analysis of a typical $\mathrm{NaOH}-\mathrm{NaOCl}$-textured c-Si surface with texturing time $>10 \mathrm{~min}$

indicated in Fig. 2b. Moreover, it was also observed that the average reflectance (wavelength range 300-1,100 nm) of textured $\mathrm{c}-\mathrm{Si}$ wafers depended on the three major experimental parameters, such as concentration of $\mathrm{NaOH}$, ratios of $\mathrm{NaOH}: \mathrm{NaOCl}$ and times of etching for a fixed $\mathrm{NaOCl}$ concentration as mentioned in Table 1. In this case, $\mathrm{NaOCl}$ plays a dominating role due to its higher amount compared to $\mathrm{NaOH}$, as a result of which the etch rate is strongly reduced in the $\langle 100\rangle$ direction and increased in the $\langle 111\rangle$ direction, resulting in a much flatter surface. Higher reflectance compared to $20 \% \mathrm{NaOH}$ in a 1:2 ratio was due to the flatter surface nature of the samples S5, S7, S9 and S10, as shown in Table 1. Figure 3 shows the nature of surface structure formed with a higher amount of $\mathrm{NaOCl}$ in the $\mathrm{NaOH}-\mathrm{NaOCl}$ solution. However, for lower time ( $\sim 10 \mathrm{~min}$ ), the samples S6, S8 and S10 showed low average reflectance. This was due to the very less etching rate of the silicon surface after the addition of $\mathrm{NaOCl}$ to the etching solution, resulting in lesser amount of contaminant removal from the surfaces of S6, S8 and S10 samples, as indicated in FTIR analysis curves (Fig. 4a-c). Therefore, we did not use the samples S6, S8 and S10 despite their lower reflectance values, because the surface contaminants were still present even after texturization. As done earlier, we thoroughly analyzed the $\mathrm{NaOH}-\mathrm{IPA}$-textured c-Si samples via optical microscopic study and FTIR analysis, respectively. It was observed from optical microscopic study throughout the entire c-Si surface that the textured c-Si surface was not at all satisfactory even after 2 min saw damage removal followed by $45 \mathrm{~min}$ of $\mathrm{NaOH}-\mathrm{IPA}$ texturization as shown in Fig. 5. FTIR analysis of the $\mathrm{NaOH}-$ IPA-textured c-Si sample showed some impurity still present on the silicon surface as indicated in Fig. 6, hindering the initiation of the texturing process. In the case of surface texturization with our proposed $\mathrm{NaOH}-\mathrm{NaOCl}$ approach, we discarded the saw damage removal step. From the optical microscopic study of the surface throughout the $\mathrm{NaOH}-\mathrm{NaOCl}$-textured surface, it was observed that the surface of c-Si was uniformly textured with the $\mathrm{NaOH}-\mathrm{NaOCl}$-texturing approach as shown in Fig. 7. The FTIR observation of $\mathrm{NaOH}-\mathrm{NaOCl}$-textured surface indicated the complete removal of organic contaminants from the surface of $\mathrm{c}-\mathrm{Si}$ during texturing in
Fig. 9 SEM micrographs of textured $\mathrm{c}-\mathrm{Si}$ surface using a conventional $\mathrm{NaOH}-\mathrm{IPA}$ solution and the $\mathbf{b}$ proposed $\mathrm{NaOH}-\mathrm{NaOCl}$ solution, respectively, for texturing
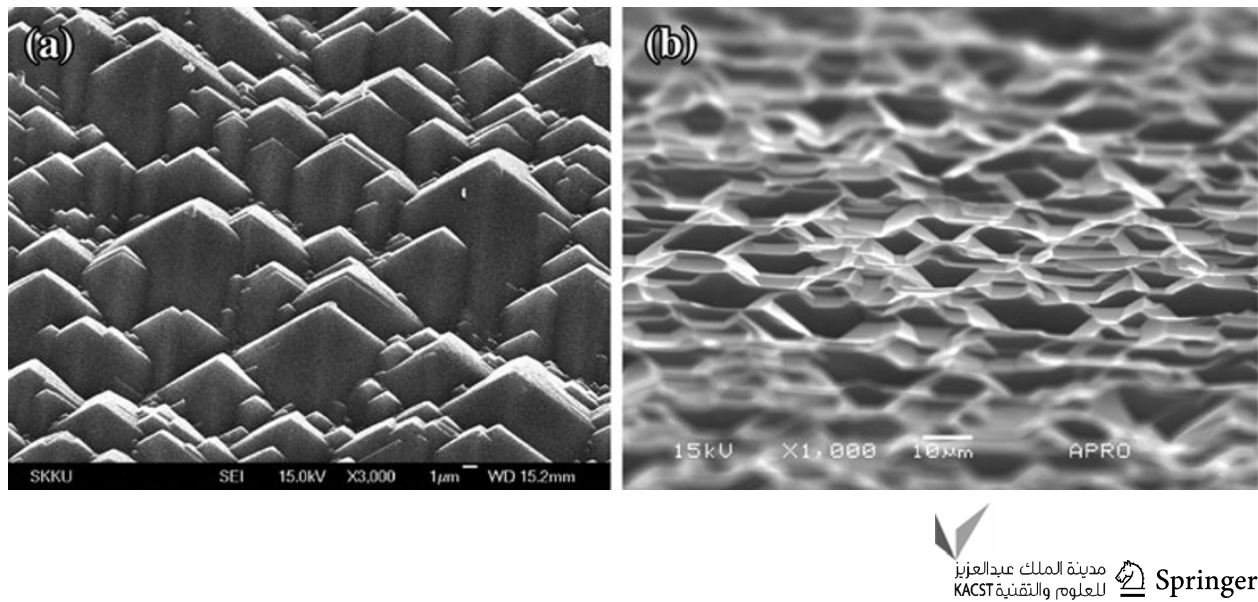
$\mathrm{NaOH}-\mathrm{NaOCl}$ bath as shown in Fig. 8. This was due to the $\mathrm{NaOCl}$ present in the texturization solution, which oxidized all organic contaminants from the c-Si surface. The oxidized contaminants thus formed were finally etched out by $\mathrm{NaOH}$ present in the textured solution. This chemical process might help in the initiation of the texturization process. From the SEM analysis as showed in Fig. 9, we observed that the nature of the $\mathrm{NaOH}-\mathrm{NaOCl}$-textured surface was entirely differently structured than that observed in the case of conventional $\mathrm{NaOH}$-IPA-textured surface. Inverted pyramidal structures might have originated on the c-Si surface during the $\mathrm{NaOH}-\mathrm{NaOCl}$ texturization sequence. Formation of inverted pyramidal structures on the c-Si surface in this case was likely observed in the case of selective texturization through an oxide mask [11]. The formation of inverted pyramid structures in the case of the proposed $\mathrm{NaOH}-\mathrm{NaOCl}$ etching might be due to the combined effect of in situ nonuniform oxidation via etching due to the presence of constituent chemicals $\mathrm{NaOCl}$ and $\mathrm{NaOH}$ in the texturing solution. The oxidizing chemical $\mathrm{NaOCl}$ present in the textured solution may help in the formation of thin, nonuniform oxide growth on the c-Si surface, and $\mathrm{OH}^{-}$in the $\mathrm{NaOH}$ solution might help in c-Si surface etching. Moreover, the chance for formation of more inverted pyramids through an unintentional opening window of oxide is more due to the highest anisotropy of the $20 \%$ concentrated $\mathrm{NaOH}$ solution.

Figure 10 shows the reflectivity of $\mathrm{c}-\mathrm{Si}$ wafers textured using conventional $\mathrm{NaOH}-\mathrm{IPA}$ and new $\mathrm{NaOH}-\mathrm{NaOCl}-$ texturing approaches. It was observed that the overall reflectance (wavelength range $300-1,100 \mathrm{~nm}$ ) of c-Si wafer textured using conventional $\mathrm{NaOH}-\mathrm{IPA}$ approach was lower than that using the proposed $\mathrm{NaOH}-\mathrm{NaOCl}$

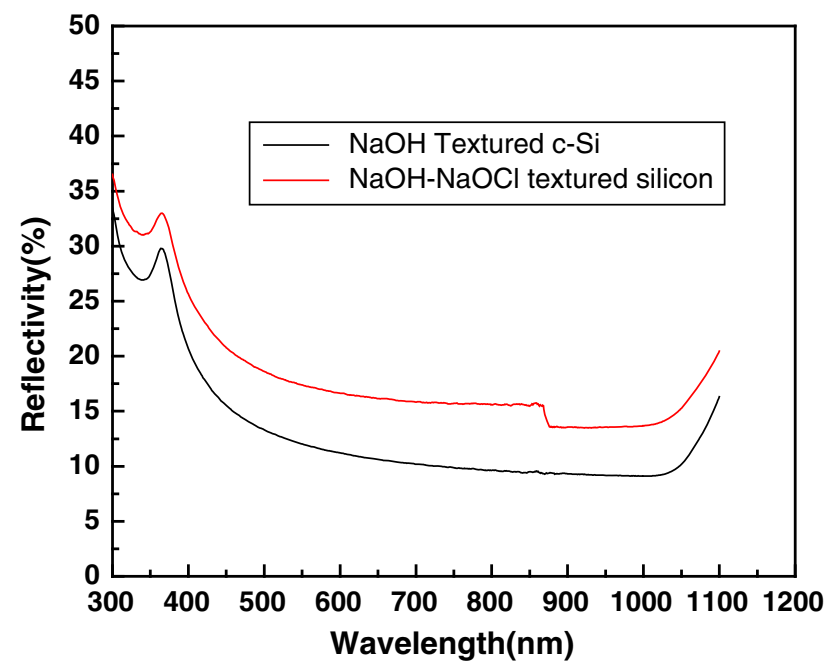

Fig. 10 Reflectance of $\mathrm{NaOH}-\mathrm{IPA}$-textured and $\mathrm{NaOH}-\mathrm{NaOCl}$-textured c-Si surfaces

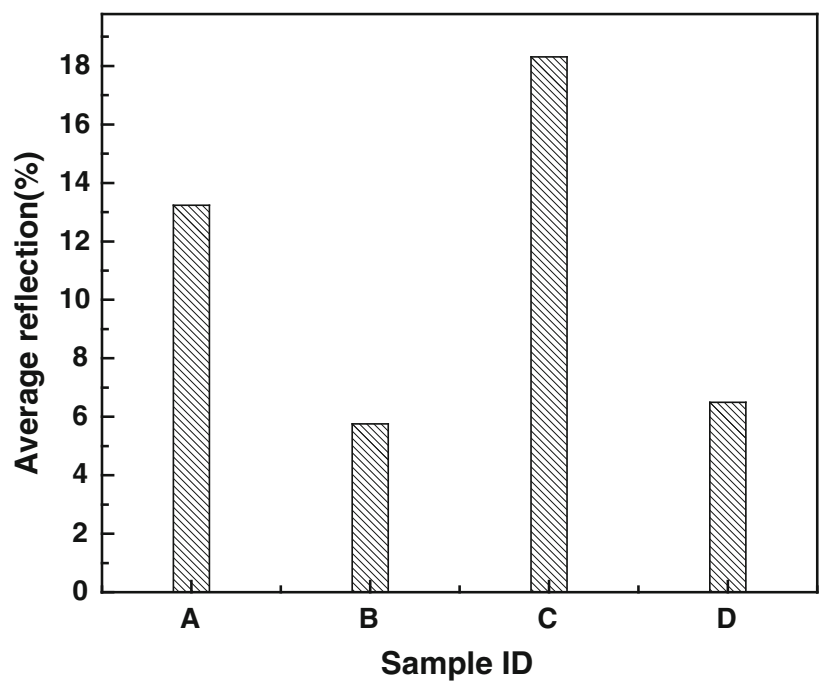

Fig. 11 Average reflectance of textured c-Si surface without silicon nitride (SiNx) ARC: NaOH-IPA textured [sample ID-A], $\mathrm{NaOH}-$ $\mathrm{NaOCl}$ textured [sample ID-C] and with SINx ARC: NaOH-IPA textured [sample ID-B] and $\mathrm{NaOH}-\mathrm{NaOCl}$ textured [sample ID-D]

approach. One important point is that the reflectivity of the c-Si surface does not have such a serious effect on the conversion efficiency of the fabricated solar cell, because $\mathrm{SiNx} / \mathrm{TiO}_{2}$ film as AR (antireflective) coating is usually used for all commercial silicon solar cells after texturization. Moreover, after SiNx coating on $\mathrm{NaOH}-\mathrm{NaOCl}-$ textured $\mathrm{c}-\mathrm{Si}$ wafer, the average reflectivity drastically reduces from $18.31 \%$ to around $6.49 \%$ whereas for $\mathrm{NaOH}$-textured $c$-Si wafer it is reduced from 13.23 to $\sim 5.75 \%$ after SiNx AR coating. as shown in Fig. 11.

Illuminated current-voltage characteristics of the fabricated c-Si cells with the $\mathrm{NaOH}-\mathrm{NaOCl}$ as well as conventional $\mathrm{NaOH}-\mathrm{IPA}$ approaches were observed under global spectrum of AM 1.5, which are shown in Fig. 12. It

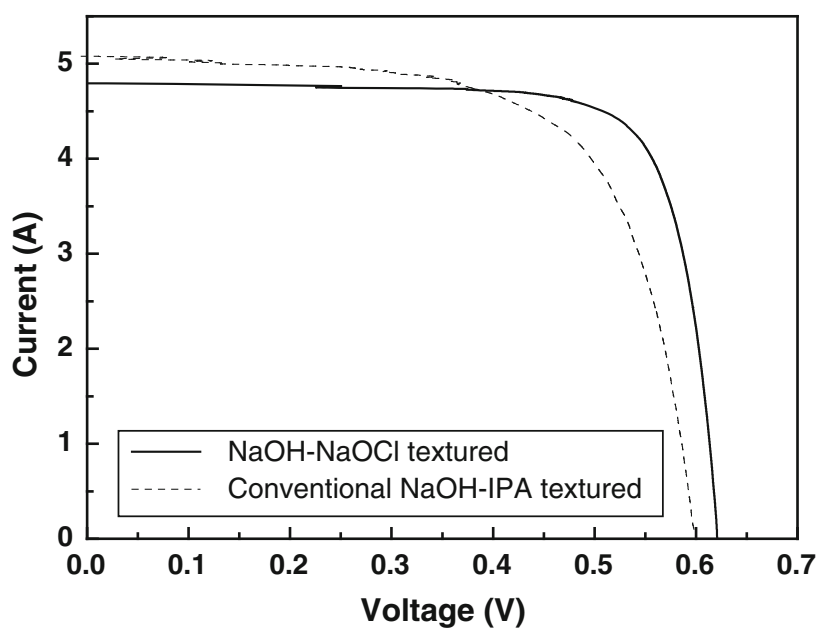

Fig. 12 LIV characteristics of $\mathrm{NaOH}-\mathrm{IPA}-$ textured and $\mathrm{NaOH}-$ $\mathrm{NaOCl}$-textured c-Si solar cells 
Table 2 Performance parameters of $\mathrm{NaOH}-\mathrm{NaOCl}$-textured and $\mathrm{NaOH}-\mathrm{IPA}$-textured large-area $(125 \mathrm{~mm} \times 125 \mathrm{~mm}) \mathrm{c}-\mathrm{Si}$ solar cells

\begin{tabular}{llllllllr}
$\begin{array}{l}\text { Texturization } \\
\text { solution }\end{array}$ & $\begin{array}{l}V_{\mathrm{oc}} \\
(\mathrm{V})\end{array}$ & $\begin{array}{l}I_{\mathrm{sc}} \\
(\mathrm{A})\end{array}$ & $\begin{array}{l}V_{\mathrm{m}} \\
(\mathrm{V})\end{array}$ & $\begin{array}{l}I_{\mathrm{m}} \\
(\mathrm{A})\end{array}$ & $\begin{array}{l}P_{\mathrm{m}} \\
(\mathrm{W})\end{array}$ & FF & $\begin{array}{l}R_{\text {sh }} \\
(\Omega)\end{array}$ & $\begin{array}{l}R_{\mathrm{s}} \\
(\mathrm{m} \Omega)\end{array}$ \\
\hline $\mathrm{NaOH}-\mathrm{NaOCl}$ & 621.4 & 4.80 & 527.10 & 4.40 & 2.32 & 0.78 & $\begin{array}{l}\text { Eff. } \\
(\%)\end{array}$ \\
$\mathrm{NaOH}$ & 598.7 & 5.08 & 472.54 & 4.29 & 2.03 & 0.67 & 6.43 & 5.00 \\
\hline
\end{tabular}

$V_{o c}$ open circuit voltage, $I_{s c}$ short circuit current, $V_{m}$ voltage at max. power point, $I_{m}$ current at max. power point, $P_{m}$ max. power output, $F F$ fill factor, Eff efficiency, $R_{s h}$ shunt resistance, $R_{s}$ series resistance

was observed from these graphs that the overall efficiency achieved in the current approach of surface texturing by using $\mathrm{NaOH}-\mathrm{NaOCl}$ was much higher than that of the conventional approach with $\mathrm{NaOH}-\mathrm{IPA}$. This was reflected in the electrical parameters of the solar cell for two different texturing approaches as shown in Table 2. The low open circuit voltage $\left(V_{\mathrm{oc}}\right)$ and fill factor $(\mathrm{FF})$ of the c-Si solar cell fabricated using $\mathrm{NaOH}-\mathrm{IPA}$ texturing might be due to its higher value of leakage current compared to the $\mathrm{NaOH}-\mathrm{NaOCl}$-textured solar cell. Reverse characteristics of dark voltage-current characteristic (DIV) as shown in Fig. 13 give a clear indication of significantly large leakage of current for $\mathrm{NaOH}$-textured compared to $\mathrm{NaOH}-\mathrm{NaOCl}-$ textured c-Si solar cells. For comparatively higher leakage current, the observed shunt resistance was lower $(6.43 \Omega)$ in the case of $\mathrm{NaOH}$-textured than that of $\mathrm{NaOH}-\mathrm{NaOCl}-$ textured $\mathrm{c}-\mathrm{Si}$ solar cell $(14.5 \Omega)$ as shown in Table 2 . Lower value of leakage current in the case of $\mathrm{NaOH}-$ $\mathrm{NaOCl}-$ textured cell might be due to uniform surface structure throughout the area $(125 \mathrm{~mm} \times 125 \mathrm{~mm})$ of $\mathrm{c}-\mathrm{Si}$ with relatively smaller steps of $<5 \mu \mathrm{m}$. As a result, no surface contaminants were present after texturing of the contaminated c-Si wafer as shown in Fig. 8. This effectively improved the dark current and also other electrical parameters of solar cells as mentioned in Table 2. The decrease in series resistance $(\mathrm{Rs}=3 \mathrm{~m} \Omega$ ) of $\mathrm{NaOH}-$ $\mathrm{NaOCl}-$ textured silicon solar cell also indicated the

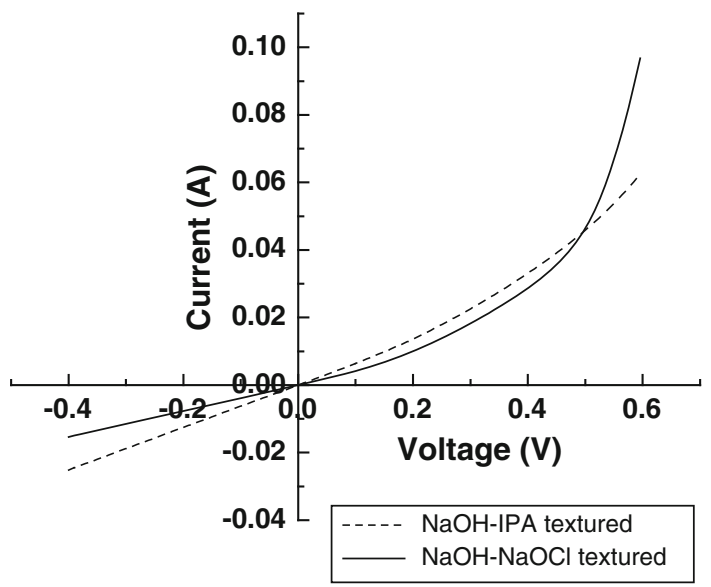

Fig. 13 DIV characteristics of $\mathrm{NaOH}-\mathrm{IPA}$-textured and $\mathrm{NaOH}-$ $\mathrm{NaOCl}$-textured c-Si solar cells

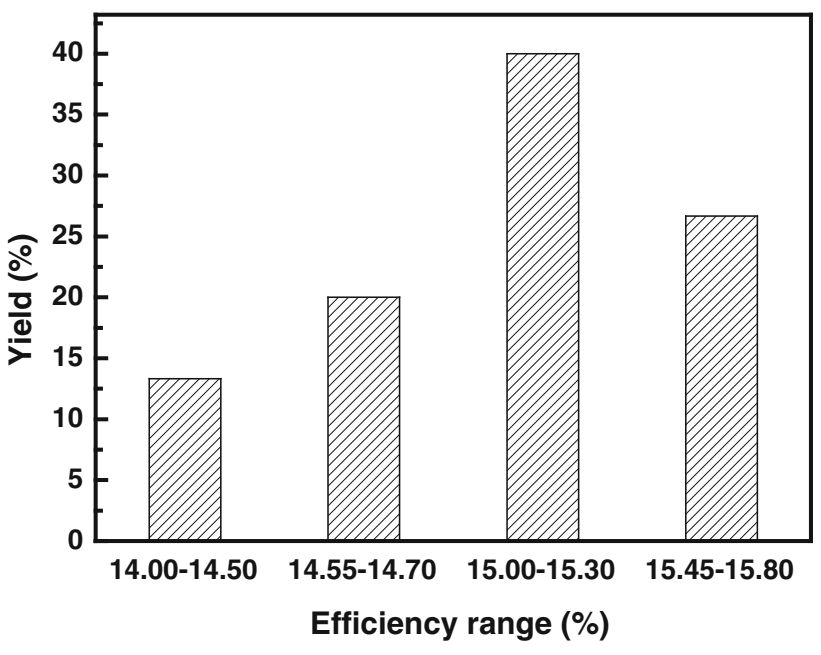

Fig. 14 Percentage of industrial yield of $\mathrm{NaOH}-\mathrm{NaOCl}$-textured large-area $(125 \mathrm{~mm} \times 125 \mathrm{~mm}) \mathrm{c}-\mathrm{Si}$ solar cell

reduction of surface contaminant present on the solar cell surface. Actually, series resistance and other electrical parameters of the solar cells were strongly dependent on front and back contacts. The presence of surface contaminants degrades the conventional $\mathrm{NaOH}-\mathrm{IPA}$-textured c-Si solar cell performance parameters, except for short circuit current as mentioned in Table 2 in spite of using a huge amount of costly IPA in the industrial process sequence. A slightly higher value of short circuit current in conventionally textured c-Si cells compared to that in $\mathrm{NaOH}-$ $\mathrm{NaOCl}$-textured cells is due to its lower value of reflectance after texturing.

We successfully achieved around $85 \%$ yield in the efficiency range 14.5-15.8\% using $\mathrm{NaOH}-\mathrm{NaOCl}$-texturing approach as shown in Fig. 14, whereas in conventional $\mathrm{NaOH}-I P A-t e x t u r e d$ solar cell the yield percentage in the efficiency range $13.5-14.0 \%$ was around $80 \%$ only, as shown in Fig. 15. Higher open circuit voltage $\left(V_{\mathrm{oc}}\right)$ of $\mathrm{NaOH}=\mathrm{NaOCl}-$ textured $\mathrm{c}-\mathrm{Si}$ solar cell compared to $\mathrm{NaOH}$ IPA-textured solar cell had two reasons. The first one was due to less etch depth $(<5 \mu \mathrm{m})$ generated on very largearea c-Si substrate with no significant surface contaminations after $\mathrm{NaOH}-\mathrm{NaOCl}$ texturing and the second reason was the effect of chlorine attachment with silicon $(\mathrm{Si}-\mathrm{Cl}$ bond) during treatment of $\mathrm{c}-\mathrm{Si}$ with $\mathrm{NaOH}-\mathrm{NaOCl}$ solution at $80{ }^{\circ} \mathrm{C}$, as shown in the FTIR characteristics of Fig. 16 . 


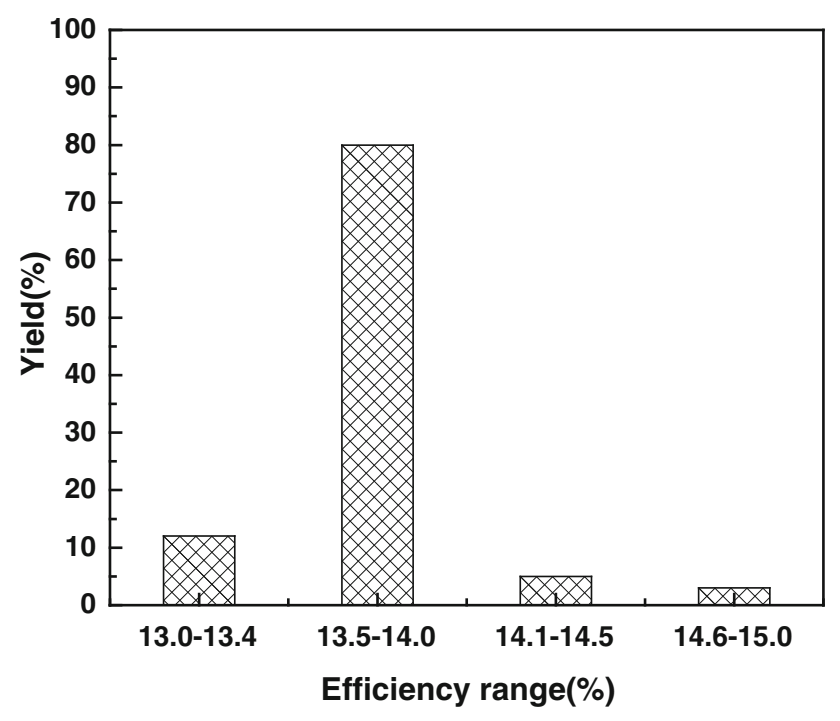

Fig. 15 Percentage of industrial yield of $\mathrm{NaOH}-\mathrm{IPA}$-textured largearea $(125 \mathrm{~mm} \times 125 \mathrm{~mm}) \mathrm{c}$-Si solar cell

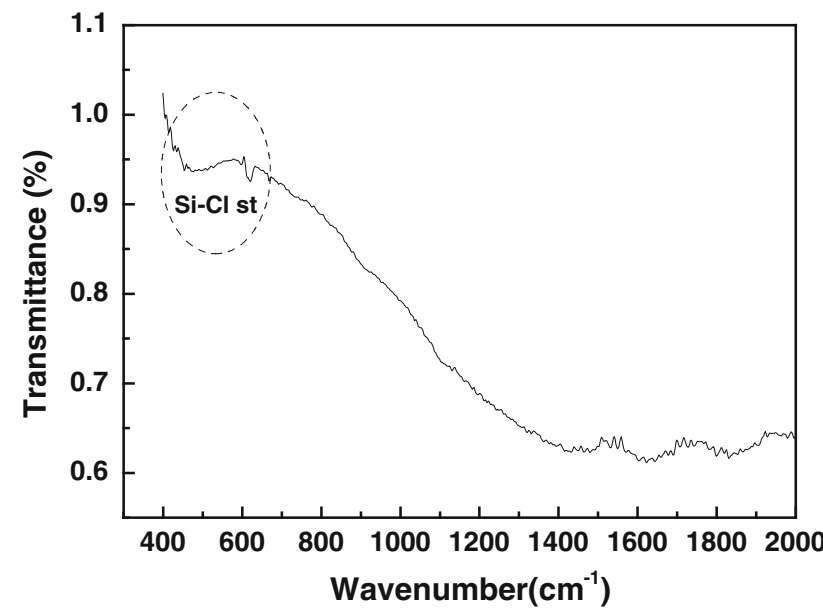

Fig. 16 FTIR analysis of $\mathrm{NaOH}-\mathrm{NaOCl}$-textured c-Si solar cell

This $\mathrm{Si}-\mathrm{Cl}$ bond might have helped the gettering during diffusion of $\mathrm{NaOH}-\mathrm{NaOCl}$-treated wafers $[10,12]$. It clearly indicates that this newly developed $\mathrm{NaOH}-\mathrm{NaOCl}$ approach of c-Si texturing discussed in this article can easily be applied to $\mathrm{c}-\mathrm{Si}$ wafer surface with additional effect of surface contamination removal for commercial production of very large-area c-Si solar cell of reasonably acceptable efficiency and contamination of $\mathrm{c}-\mathrm{Si}$ wafers even without costly IPA addition.

\section{Conclusion}

The proposed texturization technique generated inverted pyramidal structure of etch depth $4 \mu \mathrm{m}$ without any additional oxide masking step, which was normally needed for forming inverted pyramid structure during etching with any anisotropic etching solution. $\mathrm{NaOCl}$ in our proposed technique is a key material for growing in situ oxide masking layer on monocrystalline silicon (c-Si) surface during etching in $\mathrm{NaOH}-\mathrm{NaOCl}$ bath. Our findings reported in this paper are based on comparative studies of optical/SEM imaging as well as FTIR spectroscopy of the c-Si sample before and after conventional $\mathrm{NaOH}$ and proposed $\mathrm{NaOH}-\mathrm{NaOCl}$ texturization process along with the observed electrical parameters of solar cells. The comparative study of electrical parameters of the cells fabricated with conventional $\mathrm{NaOH}-\mathrm{IPA}$ and the proposed cells brings out a significant improvement of parameters for solar cells. Open circuit voltage of $621.4 \mathrm{mV}$ and a fill factor as high as 0.78 were the parameters achieved as a key for the high efficiency of $(\sim 16 \%)$ crystalline silicon solar cell of area $(125 \mathrm{~mm} \times 125 \mathrm{~mm})$ compared to conventional $\mathrm{NaOH}-\mathrm{IPA}$ approach due to its additional surface contaminant removal behavior. Moreover, FTIR analysis indicated that the $\mathrm{Si}-\mathrm{Cl}$ bond created during texturing with $\mathrm{NaOH}-\mathrm{NaOCl}$ solution finally helped in gettering during phosphorus diffusion with $\mathrm{POCl}_{3}$ dopant. This $\mathrm{Cl}$ gettering helps in the improvement of open circuit voltage of a c-Si solar cell. We are probably the first group to report on such a novel idea of using $\mathrm{NaOH}-\mathrm{NaOCl}$ solution for monocrystalline silicon surface texturing with formation of maskless inverted structured for solar cell fabrication of area $125 \mathrm{~mm} \times 125 \mathrm{~mm}$ and yield around $85 \%$ in the conversion efficiency range $14.5-15.8 \%$, compared to $80 \%$ yield in the efficiency range of $13.5-14.0 \%$ of the conventional NaOH-IPA approach. This process can be applied as a key step to the industrial production of very large-area monocrystalline silicon solar cells.

Acknowledgments The author would like to thank the Meghnad Saha Institute of Technology, TIG for providing us the infrastructural support for carrying out research activity in this area. The authors also gratefully acknowledge the DST, Government of India for financial support for carrying out solar cell-related research activity.

Open Access This article is distributed under the terms of the Creative Commons Attribution License which permits any use, distribution, and reproduction in any medium, provided the original author(s) and the source are credited.

\section{References}

1. Vazsonyi, E., De Clercq, K., Einhaus, R., Van Kerschaver, E., Said, K., Poortmans, J., Szlufcik, J., Nijs, J.: Sol. Energy Mater. Sol. Cells 57, 179-188 (1999)

2. Chitre, S.R.: Proceedings of the 13th IEEE International Photovoltaic Specialists Conference, Washington, DC, pp. 152-154 (1978) 
3. King, D.L., Buck, M.E.: Proceedings of the 22nd IEEE International Photovoltaic Specialists Conference, Las Vegas, pp. 303 308 (1991)

4. Sethi, C., Anand, V.K., Walia, K., Sood, S.C.: TECHNIA. Int. J. Comput. Sci. Commun. Tech. 5, 785-788 (2012)

5. Nishimoto, Y., Namba, K.: Sol. Energy Mater. Sol. Cells 61, 393-402 (2000)

6. Chaoui, R., Lachab, M., Chiheub, F., Seddiki, N.: Proceedings of the 14th European Photovoltaic Solar Energy Conference, Barcelona, pp. 812-814 (1997)

7. Sangeetha, V., Kanagathara, N., Sumathi, R., Sivakumar, N., Anbalagan, G.: J. Mat 2013, Article ID 262094, 1-7
8. Gangopadhyay, U., Dhungel, S.K., Mondal, A.K., Saha, H., Yi, J.: Sol. Energy Mater. Sol. Cells 91, 1147-1151 (2007)

9. Vazsonyi, E., De Clercq, K., Einhaus, R., Van Kerschaver, E., Said, K., Poortmans, J., Szlufcik, J., Nijs, J.: Sol. Energy Mater. Sol. Cells 57, 179 (1999)

10. Gangopadhyay, U., Dhungel, S.K., Kim, K., Manna, U., Basu, P.K., Kim, H.J., Karunagaran, B., Lee, K.S., Yoo, J.S., Yi, J.: Semicond. Sci. Technol. 20, 938 (2005)

11. Campbell, P., Green, M.A.: Sol. Energy Mater. Sol. Cells 65, 369-375 (2001)

12. Rivillon, S., Chabal, Y.J., Webb, L.J., Michalak, D.J., Lewis, N.S., Halls, M.D., Raghavachari, K.: J. Vac. Sci. Technol. A, 23(4) (2005) 